\title{
Production and Characterization of Lipase Enzyme Expressed by Crude Oil Contaminated Soil Isolates
}

\author{
Ndubuisi Gabriel Elemuo ${ }^{1}$, Sunday Sunday Ikiensikimama ${ }^{2}$, Chikwendu Ebenezer Ubani $^{2}$, \\ Evans Chidi Egwim³, Justice Obinna Osuoha ${ }^{1, *}$ \\ ${ }^{1}$ World Bank Africa Center of Excellence in Oilfield Chemicals Research, University of Port Harcourt, Nigeria \\ ${ }^{2}$ Department of Petroleum and Gas Engineering, University of Port Harcourt, Nigeria \\ ${ }^{3}$ Department of Biochemistry, Federal University of Technology, Minna, Nigeria
}

Copyright $\odot 2019$ by authors, all rights reserved. Authors agree that this article remains permanently open access under the terms of the Creative Commons Attribution License 4.0 International License

\begin{abstract}
Lipases are hydrolytic enzymes responsible for the hydrolysis of triacylglycerol into glycerol and free fatty acids. The biodiversity of crude oil contaminated soil was explored for the isolation of novel potent lipase producing microorganisms. In this current study, microorganisms isolated from crude oil contaminated soils were screened for lipase activity and expression. Six fungal strains namely: Yeast, Aspergillus flavus, Aspergillus niger, Verticillus sp., Penicillum sp., and Microsporum audouini demonstrated lipase producing potentials and the best two: Verticillus sp. and Penicillum sp. were selected for enzyme production and characterization. The lipase enzyme was produced in broth medium. Optimization of selected biochemical parameters reveal that optimum temperature for lipase activity was $40^{\circ} \mathrm{C}$, pH 7 with an incubation time of $168 \mathrm{~h}$ for lipase expressed by Verticillus sp. and $40{ }^{\circ} \mathrm{C}$, $\mathrm{pH} 8$ with an incubation time of $144 \mathrm{~h}$ was established for lipase expressed by Penicillium sp. The kinetic parameters of the lipase enzyme revealed that the enzymes had low $\mathrm{Km}$ (0.19 and 0.30 respectively) for the selected substrate.
\end{abstract}

Keywords Lipase, Lipase Production, Kinetic Parameters, Optimum PH and Temperature

\section{Introduction}

Lipases, classified as EC 3.1.1.3 are enzymes that catalyze the complete breakdown of oils and fats by converting them into glycerol and fatty acids (Jaiswal et al., 2017). The principal substrate for lipase enzymes are triacylglycerols. The capacity of lipase to carry out numerous chemical biotransformation is the basis for their increasing popularity in the chemical, detergent, pharmaceutical, food and oil industries. In this regard, they are extensively utilized for lipolysis of cream and fat, ripening of cheese, for the enzymatic hydrolysis of milk and for the enhancement of flavor etc. in the diary and food industries (Franken et al., 2009). Lipases are also utilized to augment the absorbency of fabrics in the textile industry, as additives for the production of washing powder in the detergent industries, for diverse transesterification reactions and production of polymers that are biodegradable (Hasan et al., 2006; Jaiswal et al., 2017).

In the oil and gas industry, the use of enzymes has been recently suggested for several applications. A robust of enzymes has been provided for tolerating oil reservoir condition by the modern biotechnology industry. Some applications of enzymes in the oil and gas company were reported by Harris and Mckay (1998). Such application includes; breaking of gel in drilling operation to avoid filter cake formation, removal of Sulphur in hydrocarbon, production of "enzyme-based acid" which is used for the purpose of treating formation damage and matrix-acidizing of carbonate, pre-treatment of biopolymers using enzyme to improve the handling characteristics of biopolymer.

Furthermore, lipases have also been employed as catalyst for enhanced production of diverse products utilized in paper, pulp and cosmetic industry (Jaiswal et al., 2017). Many thermostable bacterial lipases have been isolated and characterized (Kumar et al., 2005) from different ecological zones. Among the identified bacteria, Pseudomonas sp., Chromobacterium sp., Achromobacter sp., Serratia sp. and Alcaligenes sp. have been evaluated for possible production of lipases (Jaiswal et al., 2017).

As a matter of fact, microorganisms that has the capacity to express lipase can be isolated from numerous habitats which include: crude oil contaminated soils, deteriorated food, diary product industries and wastes from vegetable oil industries to mention but a few (Sharma et al., 2001). According to Koet et al. (2005), soils entertain diverse microorganisms that could be potent producers of lipase and other enzymes of industrial value. The screening of novel microorganisms isolated from distinct ecological 
zones for possible production of enzymes could lead to the identification of potent enzyme producers with unique characteristics like stability to diverse $\mathrm{pH}$ and temperature ranges, and broad affinity for numerous substrates (Griebeler et al., 2011). To this effect, limited information is available in lipase production capacity of diverse microorganism domicile in numerous ecological areas. Particularly, there is paucity of information about the exploration of crude oil contaminated soils in the Niger delta part of Nigeria. In this regard, we decided to explore the biodiversity of crude oil contaminated soil in Nigeria, here we isolated microorganisms, screened and evaluated their potential and capability for lipase production using standard microbiological techniques. The biochemical characteristics and kinetic properties of the produced enzyme were also evaluated.

\section{Materials and Methods}

\subsection{Sample Collection}

The crude oil contaminated soil samples were collected from Tai Local Government Area in Ogoni, River State Nigeria using an Auger as described by Osuoha et al. (2018).

\subsection{Isolation and Identification of Lipolytic Microorganisms from Crude Oil Contaminated Soil}

A tenfold serial dilution of the soil sample was done till a $10^{3}$ dilutions was obtained according to the technique previously illustrated by Agu (2017). The method reported by Osuoha et al. (2019) was used to isolate the microorganisms under aseptic conditions after serial dilution. In brief, $1 \mathrm{~mL}$ from serially diluted $10^{3}$ test tube was inoculated into a molten Saubourand dextrose agar petri dish. The plates were allowed to solidify after mixing on the bench before incubation. Afterwards, the petri dishes were incubated for three days at a temperature of $25{ }^{\circ} \mathrm{C}$ to $28{ }^{\circ} \mathrm{C}$. The petri dishes were monitored for production of colonies and they produced colonies were distinguished based on their appearance, elevation, opacity, size, color, and shape. In other to obtain pure cultures, the separated colonies were sub-cultured into different Saubourand dextrose agar. The petri dishes were incubated as described earlier after sub-culturing until the isolates became pure. The obtained pure cultures were reserved in bijou bottles after due identification via the macroscopic and morphological characteristics.

\subsection{Screening for Lipase Producing Microorganisms}

Preliminary screening for lipase production of all fungal isolates was done based on the zones of clearance produced by the organisms on the solid media (Osuoha et al., 2019). All the isolated and identified organisms were cultured on petri dishes containing Saubourand dextrose agar media supplemented with $1 \mathrm{v} / \mathrm{v}$ of olive oil as substrate for lipase. The petri dishes were incubated for $72 \mathrm{~h}$ as described earlier and then screened for the formation of zones of clearance around the colonies. Organisms that showed zones of $5 \mathrm{~mm}$ and above were selected and used for further studies (Osuoha et al., 2019).

\subsection{Enzyme Production from Selected Strains}

Microbial isolates for lipase production were selected based on the magnitude of zones of clearance formed around the colonies. Standard inoculums of the identified microbial isolates were aseptically inoculated into $500 \mathrm{~mL}$ conical flasks containing $500 \mathrm{~mL}$ of broth productive medium which contain the following: peptone $5 \mathrm{~g}$, yeast extract $5 \mathrm{~g}$, glucose $10 \mathrm{~g}, \mathrm{~K}_{2} \mathrm{HPO}_{4}(3 \mathrm{~g}), \mathrm{Na}_{2} \mathrm{SO}_{4}(2 \mathrm{~g})$, $\mathrm{MgSO}_{4} \cdot 7 \mathrm{H}_{2} \mathrm{O}(0.1 \mathrm{~g})$ and olive oil $(3 \mathrm{ml})$ for lipase production. They were incubated at $25^{\circ} \mathrm{C}$ to $28{ }^{\circ} \mathrm{C}$ on a rotary shaker $(150 \mathrm{rpm})$ for 4 days. The broth was centrifuged to remove viable cells at $3000 \mathrm{rpm}$ for $10 \mathrm{~min}$ before used for analysis.

\subsection{Lipase Activity}

Lipase activity was determined by the technique described by Plou et al. (1998) with slight modification. Lipase activity was assayed with Tween 80 as the substrate and measured spectrophotometerically at $450 \mathrm{~nm}$. The reaction mixture contained $800 \mu \mathrm{L}$ of $1 \%(\mathrm{v} / \mathrm{v})$ Tween 80 in $20 \mathrm{mM}$ Tris- $\mathrm{HCl}(\mathrm{pH} 8.5)$ and $200 \mu \mathrm{L}$ of the enzyme source. The initial absorbance was recorded immediately at $450 \mathrm{~nm}$ and the hydrolysis rate of Tween 80 was monitored by recording the change in absorbance after $5 \mathrm{~min}$.

\subsection{Optimization of Lipase Production}

\subsubsection{Effect of Incubation Time}

Optimization of the incubation period was achieved by incubating the productive medium as described in section 2.4 for seven days. Lipase activity was monitored periodically ( $24 \mathrm{~h}$ interval) in order to establish the optimum day for lipase production from the inoculated organism.

\subsubsection{Effect of Different $\mathrm{pH}$}

In order to document the optimum $\mathrm{pH}$ for lipase activity, the $\mathrm{pH}$ of the $20 \mathrm{mM}$ Tris- $\mathrm{HCl}$ buffer was varied $(3,4,5,6$, 7, 8, 910 and 11). Other conditions described in 2.5 were kept constant.

\subsubsection{Effect of Different Temperature Ranges}

In order to establish the optimum temperature for the activity of lipase expressed by, the temperature of the 
reaction medium described in section 2.5 was varied $\left(10^{\circ} \mathrm{C}\right.$, constant.

$20{ }^{\circ} \mathrm{C}, 30{ }^{\circ} \mathrm{C}, 40{ }^{\circ} \mathrm{C}, 50{ }^{\circ} \mathrm{C}, 60^{\circ} \mathrm{C}$ ) for $30 \mathrm{~min}$. Other conditions described in 2.4 were kept constant.

\subsubsection{Kinetic Properties of the Produced Enzyme}

The Vmax and Km the produced lipase enzymes were extrapolated via the Lineweaver-Burk plot. To this end, different concentration $(0.2$ to $1.80 \mathrm{v} / \mathrm{v})$ of Tween 80 was utilized to perform enzyme-substrate reaction while other reaction conditions illustrated in section 2.5 was kept

\subsection{Statistical Analysis}

All the experiments were carried out in triplicates. SPSS version 22 was utilized to obtain the mean of the results obtained.

\section{Results}

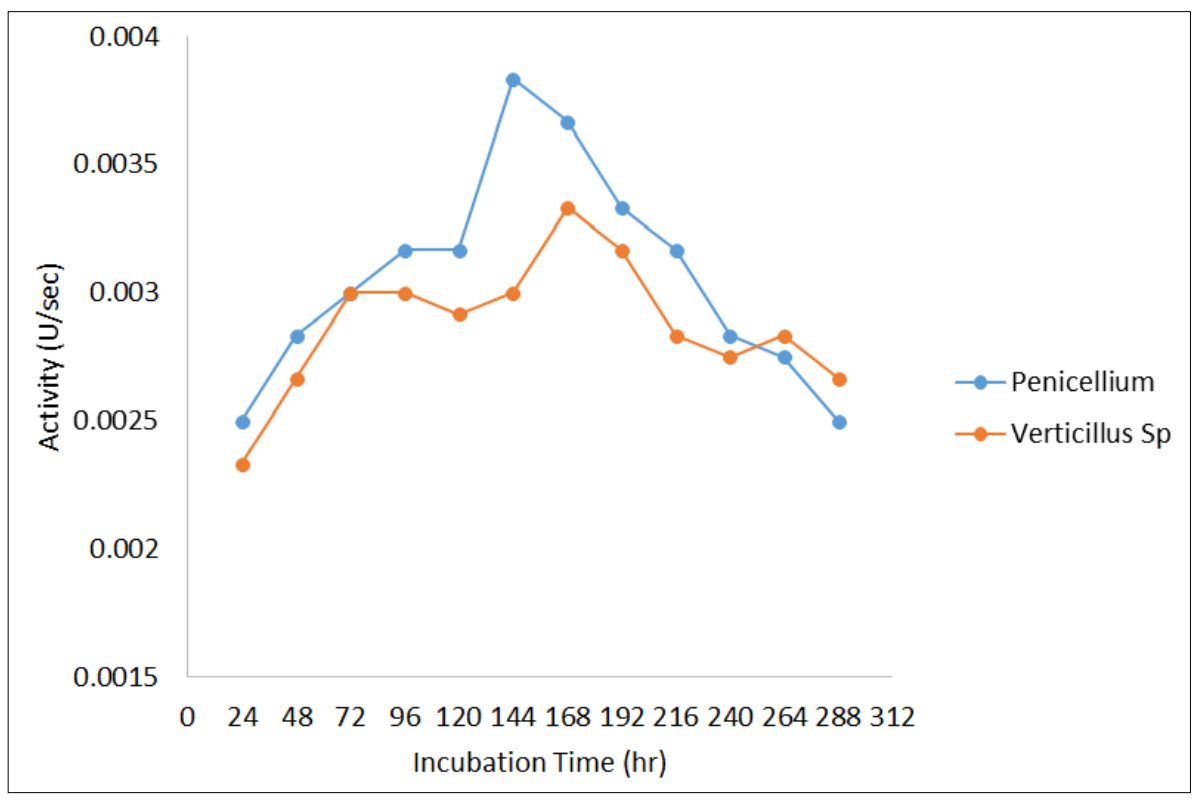

Figure 1. Effect of incubation time on the production of Lipase from Verticillus $s p$ and Penicillum isolated from crude oil contaminated soil

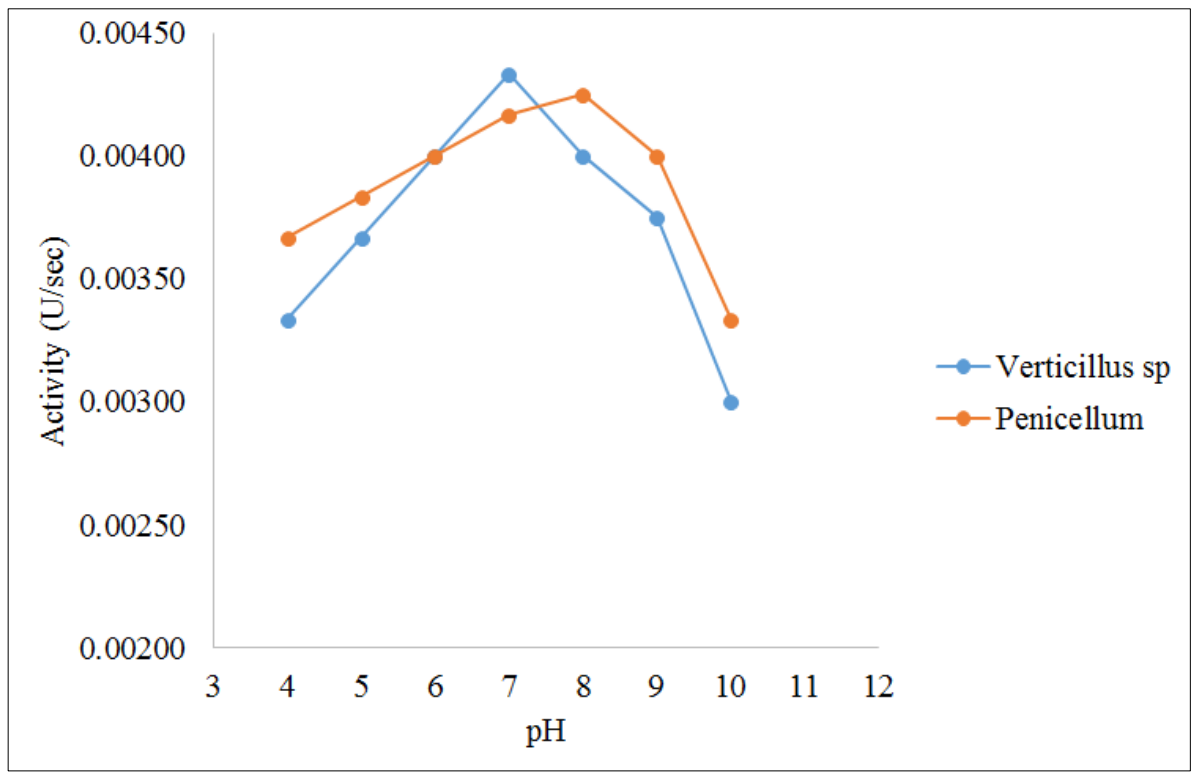

Figure 2. $\mathrm{pH}$ profile of lipases expressed by Verticillus sp and Penicellum isolated from crude oil contaminated soil 


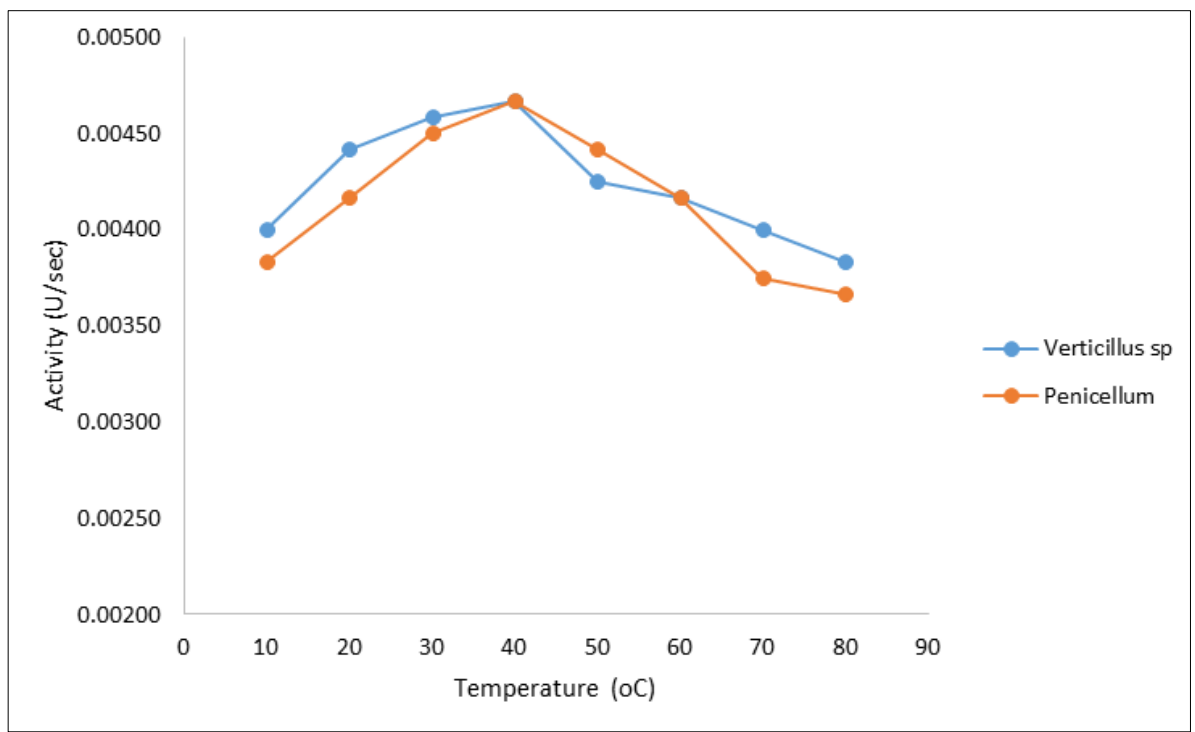

Figure 3. Temperature profile of lipases expressed by Verticillus sp and Penicellum isolated from crude oil contaminated soil

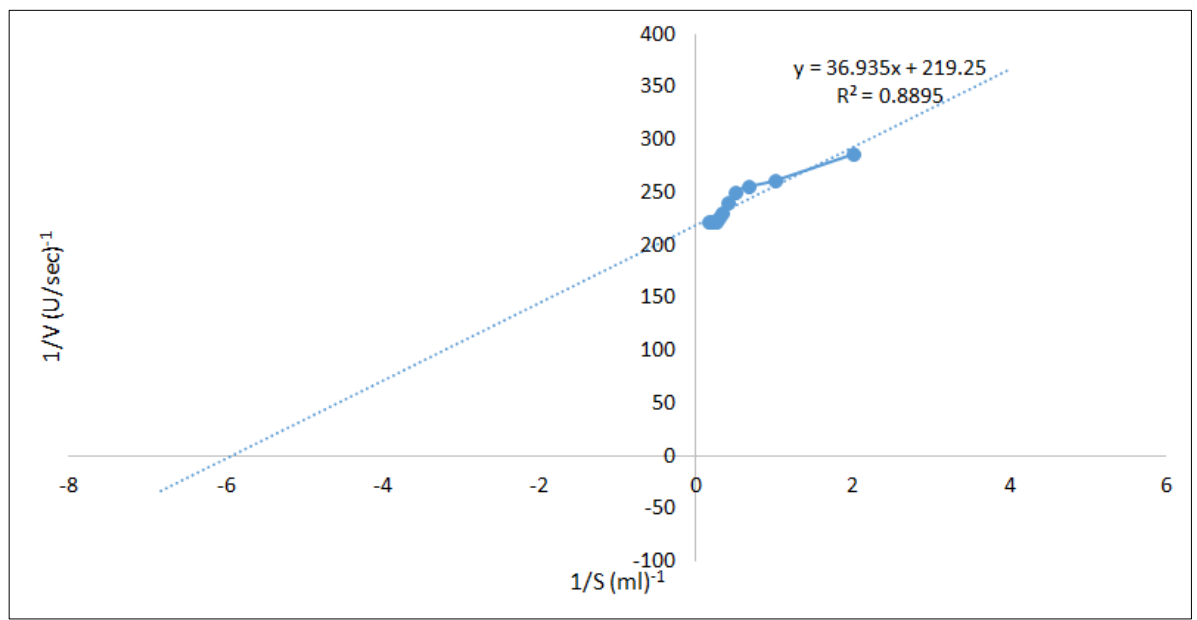

Figure 4. Enzymes substrate profile for lipases from Verticillus $s p$

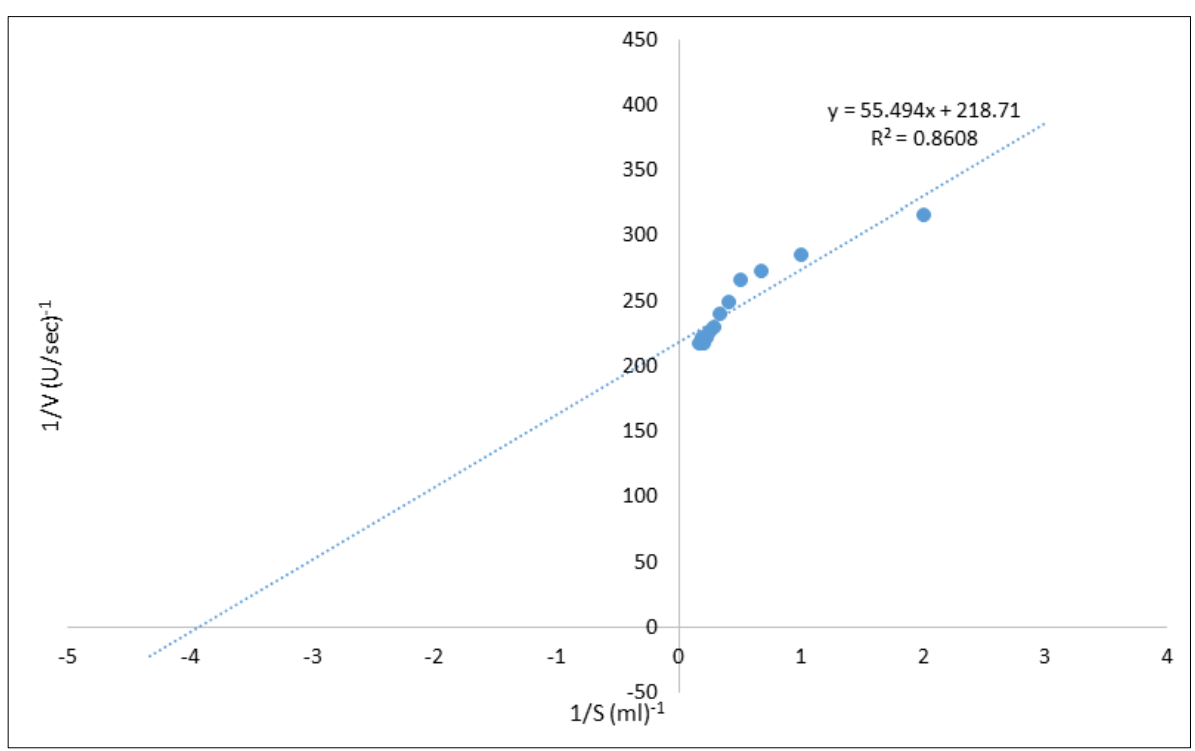

Figure 5. Enzymes substrate profile for lipases from Penicellum 


\section{Discussion}

In the present study, the biodiversity of crude oil contaminated soil was explored for the isolation of novel potent lipase producing microorganisms. Microorganisms can easily thrive in any polluted environment because of their chemotactic capability (Jorgensen, 2007) to utilize the hydrocarbons in the soil as carbon source. Crude oil contaminated soil has been reported to possess the presence of potential biodegrading microorganism thus, the reason for exploring this biodiversity. In this study, a total of twelve microbial isolates were isolated and was identified based on their macroscopic and morphological characteristics.

Preliminary examination for lipase expression capacity of the isolates was done based of the zone of clearance expressed around the fungal colonies (Osuoha et al., 2019). Out of these twelve isolates, six fungal isolates namely Yeast, Aspergillus flavus, Aspergillus niger, Verticillus sp., Penicillum sp., and Microsporum audouini demonstrated revealed good lipase producing potentials based on the magnitude of their zones of clearance (Table 1). The production of zones around microbial colonies has been utilized by numerous authors Vermelho et al. (1996), Roy et al. (2014), Dajanta et al. (2009) and more recently Osuoha et al. (2019), for the preliminary screening of enzyme production by microorganisms because it has a direct correlation of enzyme production by the organism (Roy et al., 2014). The enzyme was produced in broth medium and lipase activity was determined to confirm the presence of lipase enzyme, using tween 80 as the substrate. After lipase activity, best two organisms: Verticillus sp. and Penicillum sp. were selected for lipase production and characterization.

Table 1. Zone of clearance produced around fungal colonies for lipase production

\begin{tabular}{|c|c|c|}
\hline $\mathrm{S} / \mathrm{N}$ & Name of Organism & Zone of Clearance $(\mathrm{mm})$ \\
\hline 1 & Yeast & 1.00 \\
\hline 2 & Aspergillus flavus & 7.67 \\
\hline 3 & Aspergillus niger $^{*}$ & 6.88 \\
\hline 4 & Verticillus sp. $^{*}$ & 13.45 \\
\hline 5 & Penicillum sp. $^{*}$ & 11.23 \\
\hline 6 & Microsporum audouini & 4.70 \\
\hline
\end{tabular}

*selected for enzyme production

Furthermore, optimization of diverse fermentation conditions was performed in order to improve the activity of the produced enzyme and to establish suitable conditions for enzyme activity. The effects of incubation time on the expression of lipase from the selected isolates are presented in Figure 1. From the results, the optimum incubation time established for lipase production was 168 and $144 \mathrm{~h}$ for lipase expressed by Verticillus sp. and Penicillum sp. A steady decrease in enzyme activity was observed after the optimum day. Microbial enzyme production is not unconnected to cell growth, for this reason there is a distinctive connection between the production of enzymes by microorganism and incubation period. Microbial enzyme production is usually noticed during the peak of exponential stage or at the starting of stationery stages (Kaur et al., 1998). In this study, highest lipase productions from the selected isolates were observed at the peak of their exponential stages. The recorded decline in the activity of lipase after reaching the peak is likely due to attenuation of nutrients in the production medium which led to slowed cell metabolism and the inactivation of the enzyme (Flores et al., 1997). Our results are in consonance with those reported for lipase by Jaiswal et al. (2017).

Additionally, lipase activity has always been regulated and affected by the temperature, $\mathrm{pH}$ as wells the availability of enzyme inducers and the nature of the organism expressing the enzyme (Katz and Betancourt, 1988). Among the significant features for fascinating industrial applications of microbial enzymes, is their capacity to retain strong activity at different physical conditions. In this regard, the optimum conditions for the activity of the produced lipase were established at different $\mathrm{pH}$ and temperature ranges. As demonstrated in Figure 2, the optimal $\mathrm{pH}$ observed for lipase produced by Verticillus sp. and Penicillum sp. is 7 and 8 respectively. The optimum $\mathrm{pH}$ established in this study for both isolates is in harmony with those reported by Jaiswal et al. (2017) for lipase. Enzymes that have vast activity at different $\mathrm{pH}$ ranges are treasured in the biotechnological industries (Singhal et al. 2012).

Currently, one of the characteristics for selecting suitable industrial enzymes is their ability to remain active and perform at diverse temperature ranges. In this study, the influence of diverse temperature ranges on the activity of lipase expressed by Verticillus sp. and Penicillum sp. was examined. The highest lipase activity was observed at a temperature of $40^{\circ} \mathrm{C}$ for Verticillus sp. and Penicillum sp. respectively as presented in (Figure 3).

The Lineweaver-burk plot demonstrated in (Figure 4 and 5) was used to extrapolate the kinetic properties (Vmax and $\mathrm{Km}$ ) of lipases expressed by Verticillus sp. and Penicillum sp. The kinetic properties revealed in (Table 2), showed the lipases from Verticillus sp. and Penicillum sp. had low Km for their substrates. A low $\mathrm{Km}$ value is an indication of profound affinity for the substrate.

Table 2. Kinetic properties of the produced enzyme

\begin{tabular}{|c|c|c|}
\hline Lipase Source & Vmax $(\mathbf{U} / \mathbf{m l} / \mathbf{s e c})$ & $\mathbf{K m}(\mathbf{m M})$ \\
\hline Verticillus sp & 0.00456 & 0.1915 \\
\hline Penicellum & 0.00457 & 0.3012 \\
\hline
\end{tabular}

\section{Conclusions}

In conclusion, the fungal strains Verticillus sp. and Penicillum sp. isolated from crude oil contaminated soils 
were established to be potent lipase producers. The lipase enzyme had a high activity and was very stable at diverse temperature and $\mathrm{pH}$ ranges with vast affinity for numerous substrates. These findings uncover novel sources for microbial lipases that could be applied for numerous industrial applications.

\section{Acknowledgements}

The authors are grateful to World Bank Africa Centre of Excellence in Oilfield Chemicals Research (ACE-CEFOR), University of Port Harcourt for funding this research.

\section{REFERENCES}

[1] Dajanta, K., Wongkham, S., Thirach, P., Baophoeng, P., Apichartsrangkoon, A., Santithum, P., Chukeatirote, E. 2009. Comparative study of proteolytic activity of protease-producing bacteriaisolated from Thua nao. Maejo Int J Sci Technol, 3: 269-276

[2] Flores, M. E., Perez, R. and Huitron, C. 1997. b-xylosidase and xylanase characterization and production by Sreptomyces species CH-M-1035. Letters of Applied Microbiology, 24, 410- 416

[3] Franken, L. P. G., Marcon, N. S., Treichel, H., Oliveira, D., Freire, D. M. G., Dariva, C., et al. (2009). Food Bioprocess Technology, 3, 511-520

[4] Griebeler, N., Polloni, A. E., Remonatto, D., Arbter, F., Vardanega, R., Cechet. J. L., Di Luccio. M., de Oliveira, D., Treichel, Helen., Cansian, R. L., Rigo, E., Ninow, J. L. 2011. Isolation and Screening of Lipase-Producing Fungi with Hydrolytic Activity. Food Bioprocess Technol., 4:578-586

[5] Hasan F, Shah AA, Hameed A. 2006. Industrial applications of microbial lipases. Enzyme Microbial Tech 39: 235-251.

[6] Jaiswal A, Preet M, Tripti B. 2017. Production and Optimization of Lipase Enzyme from Mesophiles and Thermophiles. J Microb Biochem Technol 9:126-131. doi: $10.4172 / 1948-5948.1000355$

[7] Jorgensen, K.S. 2007. In situ bioremediation. Adv. Appl. Microbiol. 61, 285e305

[8] Katz, E, Betancourt A. 1988. Induction of tyrosinase by L-methionine in Streptomyces antibiotics. Can J Microbiol, 34(12): 1297-1303

[9] Kaur, M., Dhillon, S., Chaudhary, K. and Singh, R. 1998. Production, purification and characterization of thermostable alkaline protease from Bacillus polymyxa. Indian Journal Microbiology, 38, 63-67.

[10] Kumar S, Kikon K, Upadhyay A, Kanwar SS, Gupta R. 2005. Production, purification and characterization of lipase from thermophilic and alkaliphilic Bacillus coagulans BTS-3. Protein Expr Purif 41: 38-44.

[11] Osuoha, J., Iheka, C., Amadi, P., Archibong, I., Adeoti, O. 2018. Distribution and Toxicological Risk Evaluation of $\mathrm{Pb}$,
Cd, As and Zn from Surface Soils of Selected Marts in Port Harcourt, Rivers State, Nigeria. Journal of Chemical Health Risks, JCHR, 8(4), 255-264

[12] Roy, S., Das I., Munjal, M., Karthik, L., Kumar, G., Kumar, S., Rao, K.V.B. 2014. Isolation and characterization of tyrosinase produced by marine actinobacteria and its application in the removal of phenol from aqueous environment. Front. Biol. 9(4): 306-316

[13] Singhal, P., Nigam, P. and Vidyarthi, A.S. 2012. Studies on production, characterization and application of microbial alkaline protease. International Journal of Advanced Biotechnology and Research 3:23-29

[14] Vermelho, A. B., Meirelles, M. N. L., Lopes, A., Petinate, S. D. G., Chaia, A. A., Branquinha, M. H. 1996. Detection of extracellular proteases from microorganismson agar plates. MemInst Oswaldo Cruz, 91(6):755- 760

[15] Osuoha, J. O., Abbey, B. W., Egwim, E. C., and Nwaichi, E. O. 2019. Production and Characterization of Tyrosinase Enzyme for Enhanced Treatment of Organic Pollutants in Petroleum Refinery Effluent. Society of Petroleum Engineers. doi:10.2118/198791-MS 